\title{
Effects of High Plant Protein and High Soluble Fiber Beverages on Satiety, Appetite Control and Subsequent Food Intake in Healthy Men
}

\author{
Dina Fernández-Raudales ${ }^{1 *}$, Mike Yor-Aguilar ${ }^{2}$, Jose Andino-Segura² ${ }^{2}$ Adriana Hernández², \\ Russ Egbert1 ${ }^{1}$ Julio R. López-Cintrón' ${ }^{1}$ \\ ${ }^{1}$ Archer Daniels Midland Co. James R. Randall Research Center, Decatur, IL, USA \\ ${ }^{2}$ Food Science and Technology Department, Zamorano University, Escuela Agrícola Panamericana, San Antonio de Oriente, \\ F. M. Honduras
}

Email: *dina.fernandez@adm.com

How to cite this paper: Fernández-Raudales, D., Yor-Aguilar, M., Andino-Segura, J., Hernández, A., Egbert, R. and López-Cintrón, J.R. (2018) Effects of High Plant Protein and High Soluble Fiber Beverages on Satiety, Appetite Control and Subsequent Food Intake in Healthy Men. Food and Nutrition Sciences, 9, 751-762.

https://doi.org/10.4236/fns.2018.96057

Received: May 19, 2018

Accepted: June 26, 2018

Published: June 29, 2018

Copyright $\odot 2018$ by authors and Scientific Research Publishing Inc. This work is licensed under the Creative Commons Attribution International License (CC BY 4.0).

http://creativecommons.org/licenses/by/4.0/

\section{(c) (i) Open Access}

\begin{abstract}
Plant based proteins and fibers are attractive ingredients for weight management-dietary preventive strategies due to their positive satiety enhancement effects. The objective of this study was to evaluate the effect of beverages high in plant-protein and soluble fiber on satiety, appetite, hunger and subsequent food intake in healthy young men. This was a randomized crossover study with 30 normal weight male participants, BMI $23.6 \pm 1.6$ and age $22 \pm 1.4$. Volunteers consumed one high carbohydrates control (B) and 3 treatments on different days with 3-day washout period. Beverages had similar viscosity and energy content $(238 \pm 3.8 \mathrm{Kcal})$. The blank contained (B)-0 g protein $/ 2 \mathrm{~g}$ fiber), High protein (HP)-30 g protein/2g fiber, High Fiber (HF)-0 g protein/11g fiber and High protein high fiber beverage (HPHF)-30g protein/11g fiber. Visual Analogue Scales VAS were used for subjective satiety, hunger and appetite. Subsequent energy and macronutrient intake was measured by difference after consuming lunch ad libitum. Beverages HP, HF and HPHF showed higher satiety effect than $\mathrm{B}$ after 2 and 3 hours post consumption $(\mathrm{P}=$ 0.02). HP showed the most prolonged effect on satiety $(4 \mathrm{~h})$ compared to the control $(\mathrm{P}=0.02)$. Appetite control was not different between treatments but significant differences were observed against the control after $2 \mathrm{~h}$ of consumption $(\mathrm{P}=0.01)$. No differences on hunger perception, subsequent energy or macronutrient intake were observed among all beverages $(\mathrm{P}>0.05)$. The current study demonstrates that HPHF, HP and HF beverages led to improved satiety over high carbohydrate beverages. In conclusion, beverages formulated with plant-based proteins, soluble corn fiber or both may be an effective strategy to promote satiety as part of an overall weight management plan.
\end{abstract}




\section{Keywords}

Satiety, Plant-Protein, Soluble Fiber, Weight Management, Clarisoy, Profam, Fibersol

\section{Introduction}

In the past ten years interest in understanding the influence of different nutrients on appetite and satiety as dietary preventive strategies has increased. There are multiple ongoing global efforts in the scientific community, public institutions and food processors are trying to provide alternatives to improve the overall health status of a growing population. Proteins and fibers are some of the most commonly used nutritional ingredients in food and beverage products. Their positive benefits on satiety and appetite control have been studied in many different doses and forms. Protein is generally considered the most satiating macronutrient in nature [1]. A considerable body of research has been conducted on the satiating properties of proteins and high protein foods and beverages [2]-[12]. These and other studies propose several pathways and metabolic changes induced by protein in promoting satiety. Two of the most common physiological mechanisms associated with protein-satiety effects are dietary thermogenesis and the release of satiety-inducing hormones in the gastrointestinal tract [1] [13]. Another important element of discussion is the protein source and its effectiveness in promoting satiety. While some Researchers have found no differences between animal and plant based proteins on satiety [14] [15]; others have noted higher satiety effects with soy protein compared to other dairy-based proteins [16].

Fiber has a different mode of action depending on whether it is soluble or insoluble. Soluble fiber has an effect on viscosity, gelling and fermenting processes, increasing gastric distension and slowing the rate of gastric emptying which enhances the production of satiety hormones and increases the sensation of satiety, whereas insoluble fiber has a bulking effect [13]. Fiber has been described as a food intake inhibitor as well. Diets high in fiber have been associated with greater satiating effects compared to low fiber diets [17] [18], especially those described as highly viscous fibers [19]. A number of studies have been published on the positive properties of fiber on satiety and food intake [18]-[25]. Both, protein and fiber are key ingredients used by food processors to enhance weight management products but the balanced combination of carbohydrates, protein, fat and fiber is still not well understood. Chambers et al., 2015, suggested that foods might have an effect on satiety and appetite control when they are high in protein and fiber and contain more carbohydrates than fat [13]. The objective of this study was to determine the effect of beverages high in plant-based protein and/or high in soluble fiber on satiety, appetite and hunger perception and subsequent caloric and dietary intake in healthy young men. 


\section{Materials and Methods}

\subsection{Subjects}

This crossover, randomized, controlled intervention trial was conducted with healthy college-age male students of Hispanic ethnicity. Thirty individuals were voluntarily enrolled in the study after Research Ethics Approval. This research was carried out in accordance with The Code of Ethics (Declaration of Helsinki). Protocols were approved by the Ethics Review Board on Biomedical Research at the National University of Honduras (UNAH), IRB\#00003070. Inclusion criteria were: young healthy males, between 18 - 30 years old, BMI: 20 - 25, free of chronic diseases, not consuming OTC or prescribed medications, non-smokers, with no soy or dairy allergies and who customarily consume breakfast. Participants attended an information session in which they completed a background assessments interview, and anthropometric measurements after informed consent. An initial weight assessment was conducted using an electronic digital scale SECA 803. Height was measured with a portable stadiometer SECA 213. Eligible participants $(n=24)$ completed the entire study and were included in data analysis protocols.

\subsection{Study Design}

Subjects randomly consumed all treatments on different days. A three-day washout period between each treatment was required. On each intervention day, participants skipped breakfast and consumed each treatment supervised by Researchers to ensure compliance. Visual Analogue Scale (VAS) questionnaires were applied every hour post consumption to assess perceived sensation of satiety, hunger and appetite for a period of 4 hours. Participants were only allowed to drink water during the morning (6 - 11 am). An outline of the study design is shown in Figure 1.

\subsection{Beverages}

Each subject consumed three treatments and one control beverage. During the intervention period, participants received $350 \mathrm{ml}$ of each of the treatments and

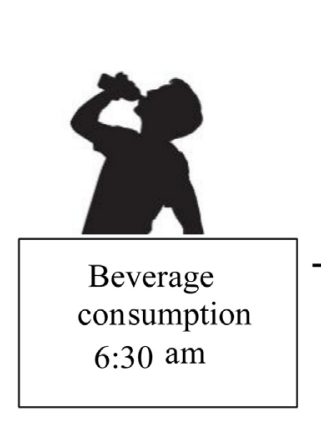

Satiety, hunger

and appetite

questionnaire
Satiety, hunger

and appetite

questionnaire
Satiety, hunger and appetite questionnaire

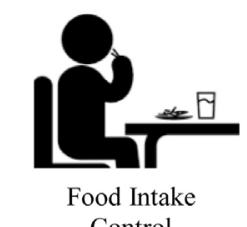
Control

Figure 1. Study design.
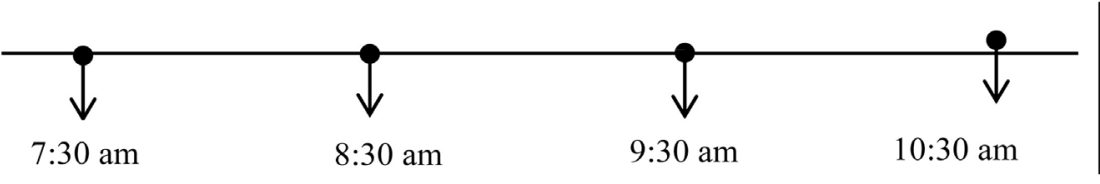

Ad-libitum

Lunch

11:30 am 
the control. Beverages were consumed early in the morning each day in which evaluations were conducted. Beverages were produced in the Food Innovation Pilot Plant of Zamorano University following Good Manufacture Practices (GMPs). Each formulation was blended, homogenized, pasteurized and bottled in glass jars with the same equipment under the same processing conditions. The beverage's viscosity were adjusted by using other ingredients in the formulation to reduce the effect of viscosity in the perception of satiety as previously suggested by Wanders et al. (2011) [19]. The control or blank (B) beverage contained $0 \mathrm{~g}$ of protein and $2 \mathrm{~g}$ of dietary fiber (DF); the High Protein (HP) beverage contained $30 \mathrm{~g}$ of protein and $2 \mathrm{~g}$ DF; the High Fiber (HF) beverage contained $11 \mathrm{~g}$ of DF and $0 \mathrm{~g}$ protein and a the HPHF beverage contained $30 \mathrm{~g}$ protein and $11 \mathrm{~g} \mathrm{DF}$. A summarized nutrient composition of all treatments and the control is shown in Table 1. Nutritional composition for all beverages was determined using AOAC protocols. Corn soluble fiber (Fibersol ${ }^{\circledR}$ ) and two soy protein isolates (Profam ${ }^{\otimes}$ and Clarisoy ${ }^{\mathrm{Tm}}$ ) were provided by Archer Daniels Midland Co, Decatur IL. All beverages provided $238 \pm 3.8 \mathrm{Kcal}$ and showed a light smoothie type texture with a creamy appearance.

\subsection{Satiety, Hunger and Appetite}

Subjective sensation of satiety, hunger and appetite were measured using a Visual Analog Scale (VAS). Subjects were asked to assess these parameters by repeated ratings using a 10-mm VAS scale anchored at either ends with the words for "not at all" and "Extremely". The intensity, time and date of the measurements were recorded by participants using assessment sheets provided by the Researchers. Each day, measurements were taken pre-consumption, at 6:30 a.m., and post-consumption at 7:30, 8:30, 9:30, and 10:30 a.m. Lunch was provided and consumed ad libitum at 11:30 a.m. in the university cafeteria where a standardized menu is served daily to all students.

\subsection{Subsequent Food Intake}

Food intake after lunch was calculated by weighing the meals pre- and post-consumption. Participants were instructed to consume as much food as desired until they were "comfortably full". All participants received a tray with the same food and beverage options during lunch time. Food consumption data during lunch was analyzed using Food Processor Nutrition Analysis Software

Table 1. Nutrient composition and energy content of beverages per portion of $350 \mathrm{ml}$.

\begin{tabular}{cccccc}
\hline $\begin{array}{c}\text { Beverage } \\
(350 \mathrm{ml})\end{array}$ & Protein $(\mathrm{g})$ & Fat $(\mathrm{g})$ & $\begin{array}{c}\text { Dietary } \\
\text { fiber }(\mathrm{g})\end{array}$ & Carbohydrates $(\mathrm{g})$ & $\begin{array}{c}\text { Energy } \\
(\text { Kcal })\end{array}$ \\
\hline HPHF & 30.45 & 2.10 & 11.20 & 24.85 & 240 \\
HP & 29.75 & 5.95 & 2.10 & 17.50 & 242 \\
HF & 0.35 & 7.35 & 10.85 & 42.70 & 238 \\
B & 0.42 & 6.95 & 2.45 & 42.26 & 233 \\
\hline
\end{tabular}


(ESHA's Food Processor $^{\circledast}$ ); total energy and macronutrient intake was assessed for each subject.

\subsection{Statistical Analysis}

Treatments effect on satiety was measured by calculating scores for the sensation of satisfaction/fullness, hunger, and desire to eat (appetite) in the interval immediately after the consumption of beverages to immediately prior to lunch. Changes in satiety, hunger and appetite scores over time and changes in scores at each time-point were analyzed with a general linear mixed model for repeated measures using Analysis of Variance (ANOVA). Duncan's Multiple Range Test (DMRT) post hoc was performed on all ANOVA measures. Energy intake and macronutrient consumption was quantified using the ESHA's Food Processor LLC $^{\circledast}$ software and the data was analyzed using one-way ANOVA. All data was reported as mean values and standard deviations or standard errors and statistical significance was accepted at $\mathrm{p}<0.05$. Statistical Analysis System $\left(S A S^{\varpi}\right)$ version 9.4 was used for all analyses.

\section{Results and Discussion}

\subsection{Participants}

Thirty volunteers enrolled in the study but only 24 were considered for further analyses due to poor compliance. Participants were healthy young men free of chronic diseases or food allergies. All subjects confirmed they regularly ate breakfast. Subject's average age was $22 \pm 1.4$ years and a mean body mass index (BMI) of $23.6 \pm 1.6 \mathrm{~kg} / \mathrm{m}^{2}$. High compliance was observed due to good training procedures, effective and constant communication between researchers and subjects and careful supervision of beverage consumption protocols.

\subsection{Perceived Satiety, Appetite and Hunger}

Our results indicate that all treatments had a significant effect on the perception of satiety at different points over a 4-hour period after consumption $(\mathrm{p}<0.001)$. No significant differences in the perception of satiety between treatments and the control were observed in the first hour post-consumption $(P=0.56)$. This indicates that the bulky effect is confined to the first hour post-consumption (Figure 2).

After 2 hours the perceived sensation of satiety was significantly higher for HP, HF and HPHF compared to the control (B) and this effect was also observed after 3 hours of consumption $(\mathrm{P}=0.02)$. After 4 hours, perception of satiety was significantly different only for HP $(\mathrm{P}=0.02)$ compared to the control. This indicates the role of protein in promoting satiety and confirms similar finding by others [2]-[12]. Also these results indicate that beverages high in protein may have a prolonged satiety effect. Data in Figure 2 show how HP extended a full hour the perception of satiety when compared to a high carbohydrate beverage (control). This results are consistent with those of Marmonier et al., 1999, who 


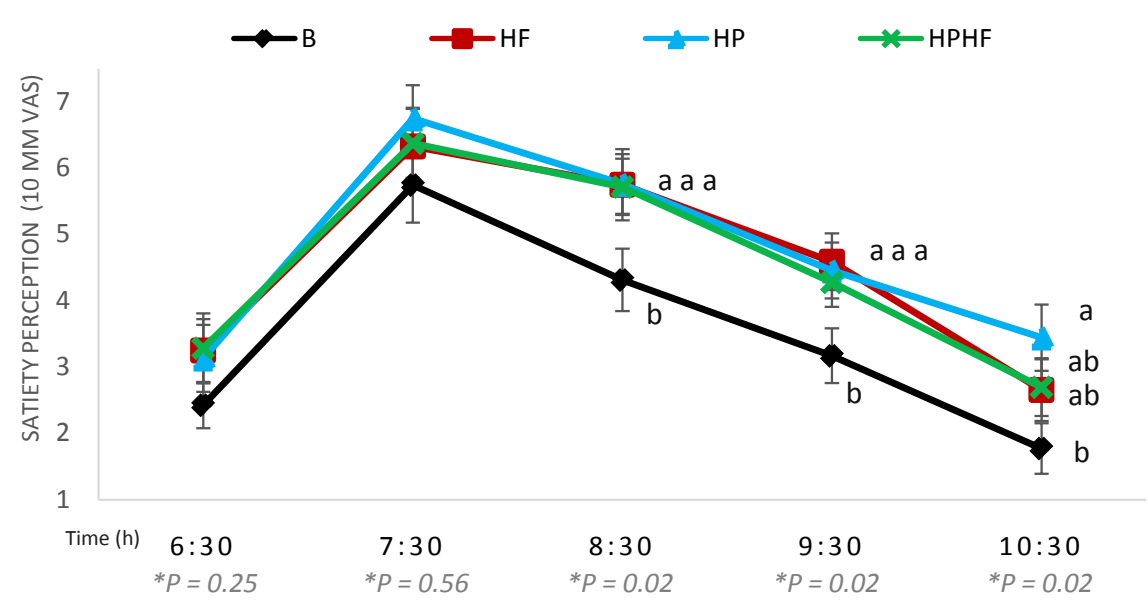

Figure 2. Satiety perception. ${ }^{\star} \mathrm{P}$-value between treatments per hour $(\mathrm{P}<0.05$ consider significant). Different letter represent significant differences between treatments per hour. ${ }^{*}$ Significant differences throughout the time per treatment $(\mathrm{P}<0.001)$. Data are Means \pm STE. Scale: $10=$ Extremely Satisfied, $0=$ not at all.

found that high-protein snacks provide a longer feeling of fullness than high-fiber and high-carbohydrates snacks [26]. Our data also supports the notion that subjective satiety and appetite perception should be assessed more than one hour post-consumption. Sunkin and Garrow (1982) were not successful in detecting differences when they evaluated satiety 60 minutes or less post-consumption [27], whereas Porrini et al. (1997) having a longer assessment period ( $>60 \mathrm{~min}$ ), had shown significant differences in satiety among macronutrients [28]. The return to hunger and food intake is usually better studied in a period of $3-7 \mathrm{~h}$ after treatments are consumed; studies taking measurements after 7 hours post-consumption have consistently failed to find differences in the perception of satiety or food intake [29]. Appetite perception was also measured to support our data on satiety. For all treatments, there was a significant time effect on the perception of appetite over the 4-hour period, with a marked reduction after 1 hour of consumption $(\mathrm{p}<0.001)$. The major difference in appetite perception was observed after 2 hours where the perception of appetite for the high carbohydrate beverage was significantly higher compared to HP, HF and HPHF $(P=0.01)$. After 3 and 4 hours the results tend to follow the same behavior and were close to significance but not statistically different (Figure 3).

Hunger perception also changed throughout time in this study $(\mathrm{P}<0.001)$ with an accentuated reduction during the first hour for all beverages. Contrary to the finding on perception of satiety and appetite, we didn't observed significant differences among treatments at any point throughout the evaluation period (Figure 4). These findings are consistent with those of Cioffi et al. (2016) where differences in satiety and appetite were observed but no significance on hunger perception or subsequent food intake were observed between whole vs refined grain pasta meals [30].

No synergistic satiety effect of fiber plus protein (HPHF) was observed in this study. Limited research has been conducted on the synergistic or additive effect 


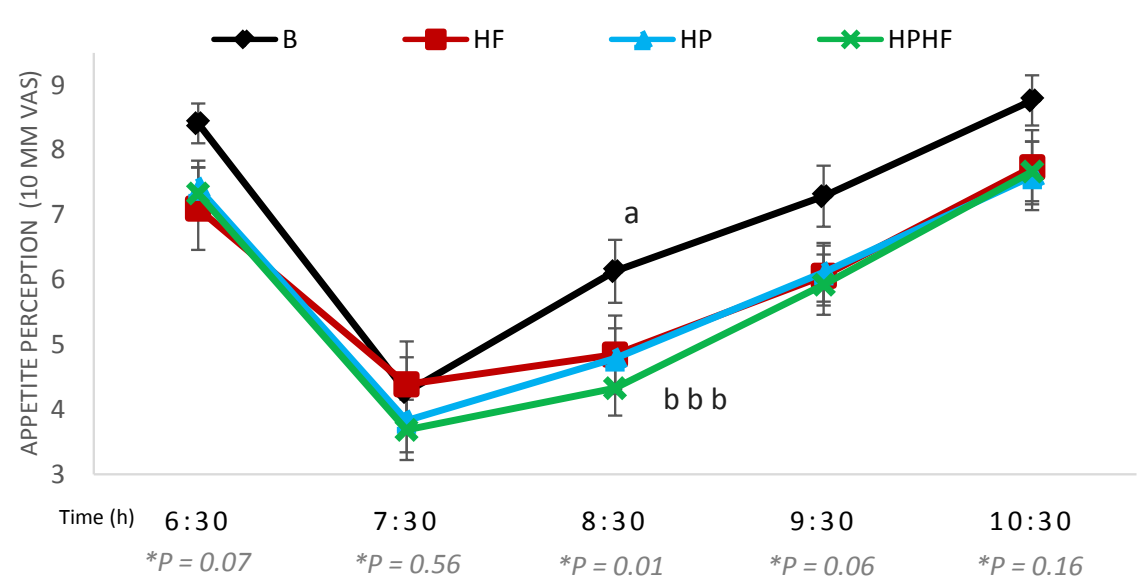

Figure 3. Appetite perception. ${ }^{\star} \mathrm{P}$-value between treatments per hour $(\mathrm{P}<0.05$ considered significant). Different letter represent significant differences between treatments per hour. ${ }^{* *}$ Significant differences throughout the time per treatment $(\mathrm{P}<0.001)$. Data are Means \pm STE. Scale: $10=$ Feel a lot appetite, $0=\mathrm{I}$ feel no appetite at all.

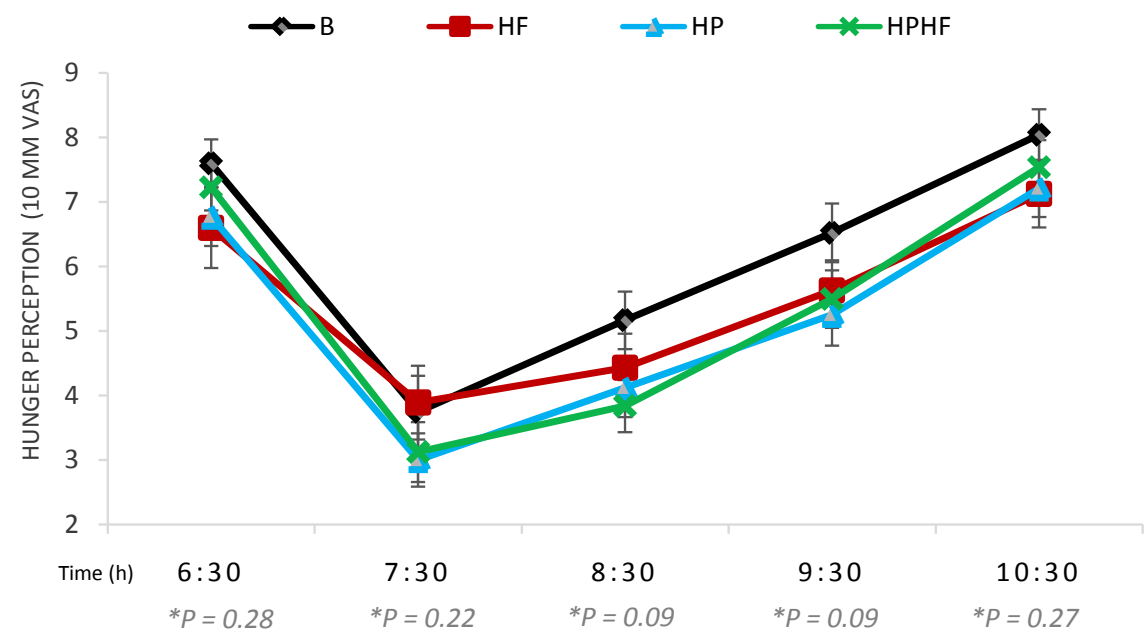

Figure 4. Hunger perception. $\mathrm{P}$-values between treatments per hour $(\mathrm{P}<0.05$ considered significant). ${ }^{* *}$ Significant differences throughout the time per treatment $(\mathrm{P}<0.001)$. Data are Means \pm STE. VAS (Visual Analog Scale): Very hungry, $0=$ not at all hungry.

of fiber and protein on satiety. A study in adult dogs by Weber et al. (2007) concluded that a combined effect of a high fiber and high protein (HPHF) meal was more satiating and reduced the voluntary intake of food more than (HP) and (HF) meals alone [31]. We can speculate that data in animal models does not translate well into human populations as there are significant differences in consumption behavior.

High protein and high fiber meals have been evaluated separately and compared to each other in previous publications. Kranz et al. (2017) emphasized the importance of providing a high-quality nutritious breakfast to preschoolers that includes both protein and fiber, however he was unable to find significant differences in the feeling of fullness when comparing meals containing high protein or high fiber [32]. Rebello et al. (2014) concluded that protein or fiber sources 
have no effect on subsequent food intake. They evaluated several fiber and protein sources such as low-fat dairy products, eggs, legumes, oats, rye, and lupin and noted that while these foods seem to enhance the perception of satiety; this doesn't always translate into a reduction in food intake [33]. This indicate how high fiber and high protein foods have a short term effects on appetite and hunger suppression, however, a deeper analysis need to be done on the right combination of satiety enhanced foods, their dose and timing of consumption to effectively asses subsequent food intake.

\subsection{Ad Libitum Lunch}

Although having a positive effect in the perception of satiety, the consumption of high protein, high fiber and high protein and fiber beverages did not resulted in a significant reduction in subsequent food intake compared to the a high carbohydrate beverage. Intake for Energy ( $812-870 \mathrm{Kcal})$, total fat $(22-26 \mathrm{~g})$, total carbohydrate (101 - $113 \mathrm{~g})$ and total protein $(41-50 \mathrm{~g})$ showed a downward trend but non-significant differences were observed between treatments $(\mathrm{P}>$ 0.05) as illustrated in Figure 5. Probable increasing the sample size, the experimental groups or extending the consumption period may help to elucidate more significant differences among treatments. These limitations should be taken into consideration for future studies.

Our results are consistent with those of Cioffi et al. (2016) who concluded

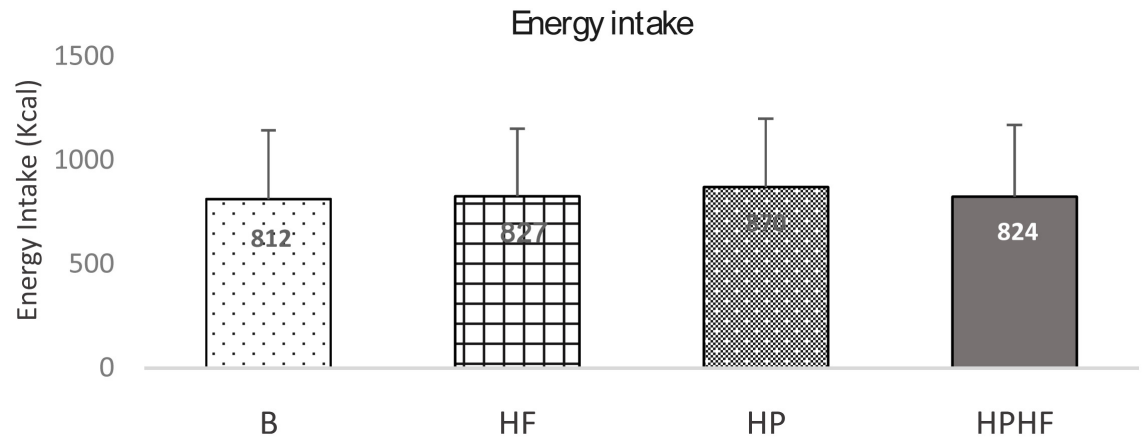

(a)

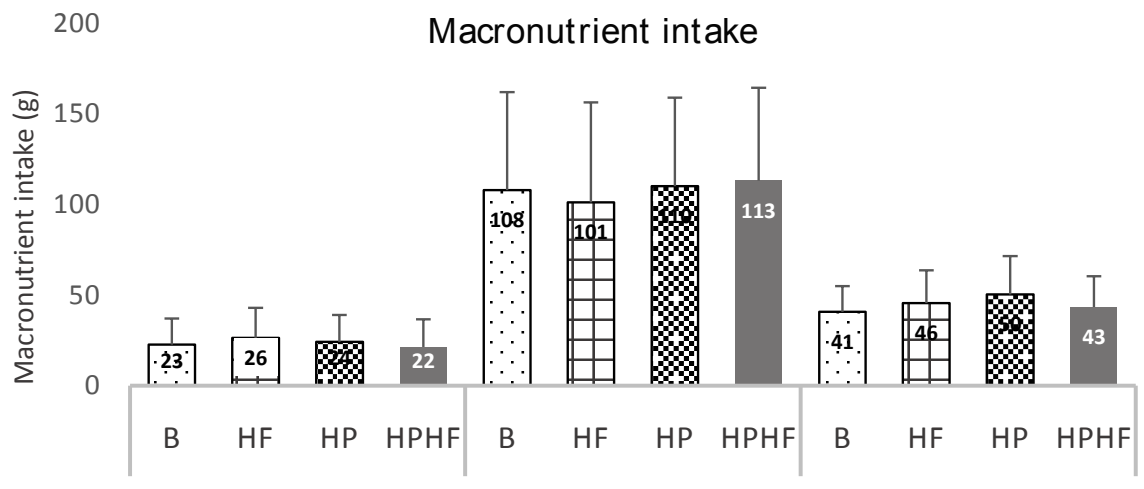

(b)

Figure 5. (a) \& (b). Subsequent (a) energy intake and (b) macronutrient intake. ${ }^{\star}$ No significant differences among treatment observed $(\mathrm{P}>0.05)$. Data are Means \pm STD. 
that a high fiber food (whole grain) increased satiety, diminished hunger perception but did not decreased energy intake after a meal was consumed ad libitum [30]. Additionally, Vuholm et al. (2013) showed that sausages fortified with fiber ingredients significantly improved the satiety effect but no subsequent ad libitum energy intake was observed [34].

Several publications have described how specific macronutrients, especially protein, have the ability to reduce food and energy intake. High protein meals (range $40-80 \mathrm{~g} / \mathrm{meal}$ ) were found to decreased energy intake $(12 \%-40 \%)$ in ad libitum meals 2 - 5 hours after consumption [28] [35] [36] [37]. Although such energy intake reduction was not observed in this trial, the effective satiety effect of high protein up to 4 hours and high fiber beverages up to 3 hours showcases the great potential to formulate products that might be effective as part of a weight management plan.

Considering the results and the timing of evaluation in this study, we conclude that beverages containing $30 \mathrm{~g}$ of plant protein or $11 \mathrm{~g}$ of soluble fiber may have the potential to control cravings and hunger feelings if consumed at mid-morning. This observation is consistent with the results obtained by Hull et al., (2015) in which subjects consuming a snack high in protein and fiber felt full for a longer period and had reduced hunger when consumed at mid-morning prior to an ad libitum meal [38].

\section{Conclusion}

Under the conditions of this study, the consumption of beverages high in soy protein and soluble corn fiber had a significant effect on satiety and appetite and had no impact on subsequent energy or macronutrient intake after 5 hours. No additive or synergistic satiety effects were observed when combining soy protein with soluble corn fiber, however, beverages high in soluble fiber and protein individually promoted satiety up to 3 and 4 hours, respectively. Our study also suggests that the timing of consumption of these macronutrients plays a role in promoting satiety and in controlling appetite. The results of this study warrant additional research on the effects of fortified food and beverages in the perception of satiety and in modulating food intake. Moreover, additional research is needed to understand the role of satiety-inducing products as part of an overall weight management strategy.

\section{Acknowledgements}

We gratefully acknowledge the participation of the Food Science and Technology students of ZAMORANO University for their participation on the present research study.

\section{Funding}

Financial support for the study was provided by ADM NUTRITION-Archer Daniels Midland Co. Decatur IL-USA. 


\section{References}

[1] Veldhorst, M., Smeets, A., Soenen, S., Hochstenbach-Waelen, A., Hursel, R., Diepvens, K., et al. (2008) Protein-Induced Satiety: Effects and Mechanisms of Different Proteins. Physiology \& Behavior, 94, 300-307. https://doi.org/10.1016/j.physbeh.2008.01.003

[2] Bertenshaw, E.J., Lluch, A. and Yeomans, M.R. (2013) Perceived Thickness and Creaminess Modulates the Short-Term Satiating Effects of High-Protein Drinks. British Journal of Nutrition, 110, 578-586. https://doi.org/10.1017/S0007114512005375

[3] Masic, U. and Yeomans, M.R. (2013) Does Monosodium Glutamate Interact With Macronutrient Composition to Influence Subsequent Appetite? Physiology \& Behavior, 116-117, 23-29.

[4] Astbury, N.M., Stevenson, E.J., Morris, P., Taylor, M.A. and Macdonald, I.A. (2010) Dose Response Effect of a Whey Protein Preload on Within-Day Energy Intake in Lean Subjects. British Journal of Nutrition, 104, 1858. https://doi.org/10.1017/S000711451000293X

[5] Bertenshaw, E.J., Lluch, A. and Yeomans, M.R. (2009) Dose Dependent Effects of Beverage Protein Content upon Short-Term Intake. Appetite, 52, 580-587. https://doi.org/10.1016/j.appet.2009.01.010

[6] Paddon-Jones, D., Westman, E., Mattes, R.D., Wolfe, R.R., Astrup, A. and Westerterp-Plantenga, M. (2008) Protein, Weight Management, and Satiety. American Journal of Clinical Nutrition, 87, 1558S-1561S. https://doi.org/10.1093/ajcn/87.5.1558S

[7] Leidy, H.J., Carnell, N.S., Mattes, R.D. and Campbell, W.W. (2007) Higher Protein Intake Preserves Lean Mass and Satiety with Weight Loss in Pre-Obese and Obese Women. Obesity, 15, 421-429. https://doi.org/10.1038/oby.2007.531

[8] Weigle, D.S., Breen, P.A., Matthys, C.C., Callahan, H.S., Meeuws, K.E., Burden, V.R., et al. (2005) A High-Protein Diet Induces Sustained Reductions in Appetite, Ad Libitum Caloric Intake, and Body Weight Despite Compensatory Changes in Diurnal Plasma Leptin and Ghrelin Concentrations. American Journal of Clinical Nutrition, 82, 41-48. https://doi.org/10.1093/ajcn/82.1.41

[9] Halton, T.L. and Hu, F.B. (2004) The Effects of High Protein Diets on Thermogenesis, Satiety and Weight Loss: A Critical Review. Journal of the American College of Nutrition, 23, 373-385.

[10] Due, A., Toubro, S., Skov, A. and Astrup, A. (2004) Effect of Normal-Fat Diets, either Medium or High in Protein, on Body Weight in Overweight Subjects: A Randomized 1-Year Trial. International Journal of Obesity, 28, 1283-1290. https://doi.org/10.1038/sj.ijo.0802767

[11] Westerterp-Plantenga, M., Lejeune, M., Nijs, I., Van Ooijen, M. and Kovacs, E. (2004) High Protein Intake Sustains Weight Maintenance after Body Weight Loss in Humans. International Journal of Obesity, 28, 57-64. https://doi.org/10.1038/sj.ijo.0802461

[12] Fischer, K., Colombani, P.C. and Wenk, C. (2004) Metabolic and Cognitive Coefficients in the Development of Hunger Sensations after Pure Macronutrient Ingestion in the Morning. Appetite, 42, 49-61. https://doi.org/10.1016/S0195-6663(03)00116-8

[13] Chambers, L., McCrickerd, K. and Yeomans, M.R. (2015) Optimizing Foods for Satiety. Trends in Food Science \& Technology, 41, 149-160. 
[14] Lang, V., Bellisle, F., Oppert, J., Craplet, C., Bornet, F., Slama, G. and Grand, B. (1998) Satiating Effect of Proteins in Healthy Subjects: A Comparison of Egg Albumin, Casein, Gelatin, Soy Protein, Pea Protein, and Wheat Gluten. The American Journal of Clinical Nutrition, 67, 1197-1204. https://doi.org/10.1093/ajcn/67.6.1197

[15] Douglas, S.M., Lasley, T.R. and Leidy, H.J. (2015) Consuming Beef vs. Soy Protein has Little Effect on Appetite, Satiety and Food Intake in Healthy Adults. The Journal of Nutrition, 145, 1010-1016. https://doi.org/10.3945/jn.114.206987

[16] Veldhorst, M.A.B., Nieuwenhuizena, A.G., Hochstenbach-Waelen, A., Westerterp, K.R., Engelen, M.P.K.J., Brummer, R.J., Deutz, N.E.P. and Westerterp-Plantenga, M.S. (2007) Effects of High or Normal Casein, Soy, or Whey with or without GMP Protein Breakfasts on Satiety, Satiety Hormones, and Plasma Amino Acid Responses. Appetite, 49, 336. https://doi.org/10.1016/j.appet.2007.03.206

[17] Madore, E. (2006) Effects of Dietary Fiber on Satiety. Thesis Master, State University of New York, Buffalo, 8-10.

[18] Howarth, N.C., Saltzman, E. and Roberts, S.B. (2001) Dietary Fiber and Weight Regulation. Nutrition Reviews, 59, 129-139. https://doi.org/10.1111/j.1753-4887.2001.tb07001.x

[19] Wanders, A.J., van den Borne, J.J.G.C., De Graaf, C., Hulshof, T., Jonathan, M.C., Kristensen, M., et al. (2011) Effects of Dietary Fibre on Subjective Appetite, Energy Intake and Body Weight: A Systematic Review of Randomized Controlled Trials. Obesity Reviews, 12, 724-739. https://doi.org/10.1111/j.1467-789X.2011.00895.X

[20] Ye, Z., Arumugam, V., Haugabrooks, E., Williamson, P. and Hendrich, S. (2015) Soluble Dietary Fiber (Fibersol-2) Decreased Hunger and Increased Satiety Hormones in Humans when Ingested with a Meal. Nutrition Research, 35, 393-400. https://doi.org/10.1016/j.nutres.2015.03.004

[21] Clark, M.J. and Slavin, J.L. (2013) The Effect of Fiber on Satiety and Food Intake: A Systematic Review. Journal of the American College of Nutrition, 32, 200-211. https://doi.org/10.1080/07315724.2013.791194

[22] Juvonen, K.R., Purhonen, A.-K., Salmenkallio-Marttila, M., Leahteenmeaki, L., Laaksonen, D.E., Herzig, K.-H., et al. (2009) Viscosity of Oat Bran-Enriched Beverages Influences Gastrointestinal Hormonal Responses in Healthy Humans. Journal of Nutrition, 139, 461-466. https://doi.org/10.3945/jn.108.099945

[23] Vuksan, V., Panahi, S., Lyon, M., Rogovik, A.L., Jenkins, A.L. and Leiter, L.A. (2009) Viscosity of Fiber Preloads Affects Food Intake in Adolescents. Nutrition Metabolism and Cardiovascular Diseases, 19, 498-503. https://doi.org/10.1016/j.numecd.2008.09.006

[24] Wynne, K., Stanley, S., McGowan, B. and Bloom, S. (2005) Appetite Control. Journal of Endocrinology, 184, 291-318. https://doi.org/10.1677/joe.1.05866

[25] Rolls, B.J., Drewnowski, A. and Ledikwe, J.H. (2005) Changing the Energy Density of the Diet as a Strategy for Weight Management. Journal of the American Dietetic Association, 105, 98-103. https://doi.org/10.1016/j.jada.2005.02.033

[26] Marmonier, C., Chapelot, D. and Louis-Silvestre, J. (2000) Effects of Macronutrient Content and Energy Density of Snacks Consumed in a Satiety State on the Onset of the Next Meal. Appetite, 34, 161-168. https://doi.org/10.1006/appe.1999.0302

[27] Sunkin, S. and Garrow, J.S. (1982) The Satiety Value of Protein. Human Nutrition: Applied Nutrition Section A, 6, 197-201.

[28] Porrini, M., Santangelo, A., Crovetti, R., Riso, P., Testolin, G. and Blundell, J.E. (1997) Weight, Protein, Fat and Timing of Preloads Affect Food Intake. Physiology and Behavior, 62, 563-570. https://doi.org/10.1016/S0031-9384(97)00162-5 
[29] Anderson, H.G. and Moore, S.E. (2004) Dietary Protein in the Regulation of Food Intake and Body Weight in Humans. The Journal of Nutrition, 134, 974S-979S. https://doi.org/10.1093/jn/134.4.974S

[30] Cioffi, I., Ibrugger, S., Bache, J., Thomaswsen, M.T., Contaldo, F., Pasanisi, F. and Kristensen, M. (2016) Effects on Satiation, Satiety and Food Intake of Wholegrain and Refined Grain Pasta. Appetite, 107, 152-158. https://doi.org/10.1016/j.appet.2016.08.002

[31] Weber, M., Bissot, T., Servet, E., Sergheraert, R., Biourge, V. and German, A.J. (2007) A High-Protein, High-Fiber Diet Designed for Weight Loss Improves Satiety in Dogs. Journal of Veterinary Internal Medicine, 21, 1203-1208. https://doi.org/10.1111/j.1939-1676.2007.tb01939.x

[32] Kranz, S., Brauchla, M., Campbell, W.W., Mattes, R.D. and Schwichtenberg, A.J. (2017) High-Protein and High-Dietary Fiber Breakfasts Result in Equal Feelings of Fullness and Better Diet Quality in Low-Income Preschoolers Compared with Their Usual Breakfast. The Journal of Nutrition, 147, 445-452.

[33] Rebello, C., Greenway, F.L. and Dhurandhar, N.V. (2014) Functional Foods to Promote Weight Loss and Satiety. Current Opinion in Clinical Nutrition \& Metabolic Care, 17, 596-604. https://doi.org/10.1097/MCO.0000000000000110

[34] Vuholm, S., Jakobsen, L.M., Sorensen, K.V., et al. (2013) Appetite and Food Intake after Consumption of Sausages with 10\% Fat and Added Wheat or Rye Bran. Appetite, 73, 205-211.

[35] Booth, D.A., Chase, A. and Campbell, A.T. (1970) Relative Effectiveness of Protein in the Late Stages of Appetite Suppression in Man. Physiology \& Behavior, 5, 1299-1302. https://doi.org/10.1016/0031-9384(70)90044-2

[36] Latner, J.D. and Schwartz, M. (1999) The Effects of a High-Carbohydrate, High-Protein or Balanced Lunch upon Later Food Intake and Hunger Ratings. Appetite, 33, 119-128. https://doi.org/10.1006/appe.1999.0237

[37] Barkeling, B., Rossner, S. and Bjorvell, H. (1990) Effects of a High-Protein Meal (meat) and a High-Carbohydrate Meal (Vegetarian) on Satiety Measured by Automated Computerized Monitoring of Subsequent Food Intake, Motivation to Eat and Food Preferences. International Journal of Obesity, 14, 743-751.

[38] Hull, S., Re, R., Chambers, L., Echaniz, A. and Wickman, M.S.J. (2015) A Mid-Morning Snack of Almonds Generates Satiety and Appropriate Adjustment of Subsequent Food Intake in Healthy Women. European Journal of Nutrition, 54, 803-810. https://doi.org/10.1007/s00394-014-0759-z 